\title{
Strategi Sekolah dalam Membentuk Sikap Disiplin Peserta Didik di SD Negeri 01 Kinali
}

\author{
Risna Noviana1, Rini Rahman ${ }^{2}$ \\ novianarisna927@gmail.com¹, rinirahman@fis.unp.ac.id ${ }^{2}$ \\ Universitas Negeri Padang ${ }^{1,2}$
}

\begin{tabular}{l}
\hline ARTICLE INFO \\
\hline Article history: \\
Received 6 Mei 2021 \\
Revised 10 Mei 2021 \\
Accepted 31 Mei 2021 \\
\hline Keywords: \\
Strategi, Sikap Disiplin, \\
Peserta Didik Sekolah \\
Dasar.
\end{tabular}

\section{Clonflict of Interest:}

None

\section{Funding:}

None

\section{ABSTRACT}

Penelitian ini untuk melihat strategi kepala sekolah dan pendidik dalam membentuk sikap disiplin peserta didik, kendala yang ditemukan pendidik dalam membentuk sikap disiplin peserta didik, selanjutnya bagaimana solusi dalam menghadapi kendala tersebut. peneltian ini menggunakan metode kualitatif dengan pendekatan deskriptif. Sumber data diambil dari sembilan orang informan melalui wawancara langsung ke lapangan yang terdiri dari kepala sekolah, wali kelas, guru Pendidikan Agama Islam, dan peserta didik. Untuk memperkuat data penelitian, penulis juga mengambil data melalui observasi dan dokumentasi. Seluruh data wawancara dianalis dengan cara pengumpulan, reduksi, penyajian dan diakhiri dengan pengambilan kesimpulan. Secara keseluruhan hasil penelitian mendapati bahwa, pertama, pada aspek strategi terdapat lima langkah yang dilakukan kepala sekolah dan pendidik dalam membentuk sikap disiplin yaitu keteladanan, pembiasaan, mensosialisasikan peraturan, memberikan hukuman serta memberikan reward atau hadiah bagi peserta didik yang memiliki sikap disiplin yang baik. Kedua, kendala yang ditemukan yaitu kurangnya kesadaran peserta didik akan pentingnya memilki sikap disiplin, minimnya pengetahuan peserta didik terhadap peraturan atau tata tertib sekolah, dan peserta didik terpengaruh oleh lingkungan pergaulannya. Ketiga, solusi yang dilakukan yaitu kerja sama antara elemen-elemen sekolah dan kerja sama antara guru dan orang tua peserta didik.

Corresponding Author: Risna Noviana, Department Islamic Education, Faculty of Social Science, Universitas Negeri Padang, Indonesia, Email: novianarisna927@gmail.com Phone: +62813-7418-7256 
Risna Noviana dan Rini Rahman: Strategi Sekolah dalam Membentuk Sikap Disiplin Peserta Didik...

\section{Pendahuluan}

Pendidikan merupakan hal yang terpenting dalam pembangunan kehidupan berbangsa dan bernegara. Dalam Undang-Undang No. 20 Tahun 2003 Pasal 3 telah ditetapkan bahwa tujuan pendidikan nasional ialah untuk mengembangkan potensi dalam diri peserta didik supaya dapat menjadi seseorang yang beriman dan bertaqwa, memiliki akhlak mulia, berilmu, sehat, cakap, mandiri, keatif, serta menjadi warga negara yang demokratis dan juga bertanggung jawab(Syafril, 2017). Sekolah ialah lembaga pendidikan yang memiliki peran besar dalam mencapai tujuan dalam sebuah pendidikan. Di dalam sebuah sekolah terdapat aturan atau norma yang telah ditetapkan untuk mengatur kepribadian dan tingkah laku seseorang. Jika sebuah sekolah memiliki disiplin yang baik, tentu akan melahirkan kondisi yang baik pula, nyaman, tentram dan teratur (Darmadi, 2017).

Disiplin merupakan suatu tindakan seseorang yang menunjukkan perilaku tertib dan patuh pada berbagai peraturan. Disiplin peserta didik ialah sikap ataupun perilaku yang menampakkan bahwa peserta didik tersebut tertib dan teratur di sekolah, dan tidakmelakukan pelanggaran-pelanggaran terhadap peraturan yang berlaku. Oleh karena itu disiplin sekolah merupakan sebuah upaya yang dilakukan oleh pendidik dalam mengatur sikap peserta didiknya dengan tegas melalui aturanaturan yang berlaku yaitu dengan adanya tata tertib sekolah untuk menuju perubahan yang lebih baik (Yusdiani, 2018).

Seperti yang kita ketahui bersama bahwa akhir-akhir ini disiplin peserta didik sangat menurun. Hal ini terjadi karena beberapa faktor diantaranya faktor keluarga, dan faktor lingkungan pergaulan peserta didik.Selain itu, teknologi selain memilki pengaruh yang baik untuk peserta didik juga memiliki pengaruh yang buruk. Kecanggihan tekhnologi sekarang memilki pengaruh buruk bagi peserta didik seperti peserta didik menggunakan handphone, dan ini akan menjadi salah satu penyebab menurunnya sikap disiplin pada diri peserta didik. Internet selain memberikan pengaruh positif kepada peserta didik juga memberikan pengaruh negatif. Hal ini dapat dilihat dari keantusiasan mereka dalam bermain game daripada sarana yang digunakan untuk belajar. Akibat dari hal ini kedisiplinan peserta didik di sekolah akan menjadi menurun (Hidayatullah, 2010).

Sekolah harus mempunyai strategi-strategi tertentu dalam membentuk sikap disiplin peserta didik terhadap peraturan yang ditetapkan sekolah. Seorang pendidik harus mampu menggunakan strategi menarik dalam pembentukan sikap disiplin peserta didik di sekolah (Asfiati, 2020). Menjadi seorang pendidik harus selalu tanggap terhadap perubahan zaman sehingga mampu melakukan inovasi-inovasi yang sesuai dengan kebutuhan pendidikan. Seorang pendidik tentunya memiliki strategi tertentu untuk membentuk sikap disiplin dalam diri peserta didik contohnya memberikan keteladanan yang baik, melakukan pembiasaan-pembiasaan bersikap disiplin, memberikan reward sebagai bentuk apresiasi bagi mereka yang disiplin, serta memberikan hukuman kepada peserta didik yang melanggar peraturan sekolah. 
Jadi, dengan adanya strategi-strategi yang dilakukan, maka pendidik akan lebih mudah untuk membentuk dan menanamkan sikap disiplin kepada peserta didik (Gunawan, 2019).

SD Negeri 01 Kinali adalah salah satu sekolah Negeri yang berlokasi di Jorong Mandiangin, Nagari Katiagan, Kecamatan Kinali. Sekolah ini merupakan sekolah favorit bagi masyarakat sekitar.SD Negeri 01 Kinali selalu menanamkan sikap disiplin yang baik kepada peserta didik melalui serangkaian tata tertib atau peraturan yang berlaku di sekolah tersebut. Sekolah ini menerapkan berbagai strategi yang menarik dalam membentuk sikap disiplin peserta didik seperti memberikan reward sebagai bentuk apresiasi dari sekolah bagi peserta didik yang memiliki sikap disiplin yang bagus.

Berdasarkan observasi yang dilakukan di SD Negeri 01 Kinali pada tanggal 16 sampai 22 Februari penulis telah melakukan wawancara bersama kepala sekolah dan wali kelas bahwa di SD Negeri 01 Kinali ini pihak sekolah telah memberlakukan tata tertib sekolah untuk dipatuhi peserta didik agar mereka selalu melaksanakan sikap disiplin di sekolah. Namun sikap disiplin peserta didik di sekolah ini perlu ditingkatkan lagi dalam mematuhi peraturan yang ditetapkan sekolah, karena masih banyak diantara peserta didikditemukan tidak disiplin dan tidak mematuhi peraturan yang berlaku di SD Negeri 01 Kinali. Pelanggaran yang sering terjadi diantaranya adalah peserta didik tidak disiplin dalam berpakaian atau tidak berpakaian dengan rapi, terlambat datang ke sekolah,tidak tertib pada saat melaksanakan upacara bendera, membuang sampah sembarangan tempat, mencoret-coret tembok sekolah, menyerahkan tugas tidak tepat waktu, kurangnya intropeksi diri dalam melaksanakan peraturan kelas misalnya keluar masuk kelas dalam proses pembelajaran, bermain handphone pada saat proses pembelajaran sedang berlangsung, dan lain sebagainya.

\section{Tinjauan Pustaka}

Disiplin merupakan suatu tindakan menunjukkan perilaku teratur dan patuh kepada setiap peraturan ataupun ketentuan yang berlaku. Disiplin adalah sebuah proses pengarahan untuk mencapai tindakan atau sebuah perilaku yang lebih baik. Dengan adanya sikap disiplin yang baik dalam diri seseorang maka akan terbentuklah sebuah perilakuyang baik pada diri seseorang tersebut, sehingga seseorang dapat memahami peraturan dan akan melaksanakan peraturan-peraturan yang ada (Gunawan, 2019).

Adapun tujuan sikap disiplin menurut Susanto (2018) yaitu dengan adanya sikap disiplin dalam diri seorang individu maka akan menjadikan seseorang berperilaku yang baik dan tidak menyimpang, dengan disiplin maka peserta didik akan terdorong untuk melakukan hal-hal positif dan juga bermanfaat, sikap disiplin akan membantu peserta didik untuk beradaptasi dengan segala peraturan di sekolah dan akan menjaga sikapnya agar tidak melakukan pelanggaran di sekolah, peserta didik yang memilki sikap disiplin maka akan membantu mereka dalam mendapatkan 
Risna Noviana dan Rini Rahman: Strategi Sekolah dalam Membentuk Sikap Disiplin Peserta Didik...

pembelajaran, karena mereka terbiasa melaksanakan kebiasaan-kebiasaan yang memilki manfaat di lingkungan sekolah.

Menurut Aditya (2018: 42) indikator peserta didik yang disiplin antara lain yaitu datang lebih awal ke sekolah sesuai waktu yang sudah ditetapkan, mengenakan atribut seragam sekolah dengan lengkap, berpakaian sekolah dengan bersih dan rapi, memberikan surat pemberitahuan ke sekolah, Apabila tidak dapat mengikuti proses pembelajaran, mengatur waktu belajar, mengikuti kegiatan proses belajar mengajar dengan baik serta dapat aktif di kelas, mengikuti dan melaksanakan kegiatan ekstrakurikuler yang di tentukan di sekolah, selalu mengerjakan dan menyerahkan tugas yang diberikan oleh guru dengan tepat waktu, selalu melaksanakan piket kelas sesuai jadwal masing-masing, kemudian mengakhiri kegiatan pembelajaran dan pulang sesuai jadwal yang ditentukan.

Strategi dalam membentuk sikap disiplin pada peserta didik Menurut Gunawan (2019) dapat dilakukan dengan upaya memberikan keteladanan, pembiasaan, upya penyadaran, pengawasan dan kontrol, mensosialisasikan peraturan, memberikan hukuman bagi peserta didik yang tidak disiplin, serta memberikan hadiah atau reward bagi peserta didik yang memilki disiplin yang bagus di sekolah.

Menurut Mulyasa (2013) kepala sekolah merupakan pimpinan dalam sebuah sekolah yang mana ia sangat menentukan dinamika sekolah menuju sebuah sekolah yang sukses dan maju. Setiap efektifitas kepemimpinan yang dilakukan oleh seorang kepala sekolah tentu memilki pengaruh yang besar terhadap kesuksesan sebuah sekolah. Kepala sekolah memilki keluasan pikiran, kedalaman ilmu, kewibawaan dan kepandaiandalam berkomunikasi akan membawaperubahan signifikan dalam manajemen sekolah. Tugas kepala sekolah menurut Kusnandar (2011) antara lain yaitu membuat program sekolah, menjalin komunikasi yang baik antar elemenelemen sekolah, pengorganisasain sekolah, menata lingkungan dan kepegawaian sekolah.

Pendidik merupakan seseorang yang memilki tanggung jawab terhadap pelaksanaan pendidikan. Pendidik bertanggung jawab mentransfer ilmu dan pengetahuan kemudian memberikan pembelajaran yang menyenangkan kepada peserta didik agar tercapainya tujuan dalam sebuah proses pembelajaran. pendidik memilki peran besar dalam membentuk sikap disiplin peserta didik (Gunawan, 2019).

\section{Metodologi}

Penelitian ini menggunakan metode kualitatif dengan pendekatan deskriptif, sumber data penelitian diambil kepada enam belas informan melalui wawancara langsung, dua puluh orang tersebut terdiri dari satu orang kepala sekolah, enam orang wali kelas, satu orang guru pendidikan agama islam, dan delapan orang peserta didik. Untuk memperkuat data penelitian, penulis juga mengambil data melalui 
observasi kepada pendidik yang sedang memberikan pembelajaran tentang kedisplinan kepada peserta didik dan juga peserta didik yang sedang mengikuti pelajaran ataupun berada di luar jam pelajaran. Selanjutnya sebagai bukti penulis menjalankan penelitian terkait isu dan permasalahan yang dikaji, maka penulis juga mengabadikan seluruh kegiatan yang dilakukan seperti wawancara langsung dengan informan aktifitas belajar peserta didik, dan strategi pendidik membentuk sikap disiplin peserta didik. Data wawancara penulis dengan informan dianalisis dengan cara model analisis Miles Huberman (2009), ananlisis data menurut Miles dan Huberman dimulai dari pengumpulan data data, reduksi data, penyajian data, dan diakhiri dengan pengambilan kesimpulan. Cara yang digunakan peneliti dalam menguji keabsahan data yaitu menggunakan triangulasi. Triangulasi merupakan sebuah cara mengkaji keabsahan data dengan memanfaatkan berbagai sumber, berbagai waktu dari data yang telah dikumpulkan (Sugiyono, 2007).

\section{Hasil dan Pembahasan}

\section{Strategi Kepala Sekolah dan Pendidik Dalam Membentuk Sikap Disiplin Peserta Didik di SD Negeri 01 Kinali}

Ada beberapa strategi yang diterapkan kepala sekolah dan pendidik dalam membentuk sikap disiplin peserta didik di sekolah terlihat dari hasil wawancara penulis dengan kepala sekolah, wali kelas, dan guru pendidikan agama islam yaitu:

Pertama, dengan keteladanan. Ini sesuai dengan pendapat bapak Muksin hasil wawancara pada tanggal 23 Maret 2021, beliau menyampaikan bahwa: "Sebagai pimpinan sekolah saya selalu memberikan contoh-contoh perilaku yang baik bagi semua warga sekolah. Contohnya saya kalau berangkat ke sekolah selalu saya usahakan berangkat sebelum Bapak/Ibu guru datang.harapannya supaya mereka melihat kalau pimpinannya berangkat duluan ke sekolah. Dan akan menjadi motivasi bagi mereka, dan juga peserta didik dapat meneladani dengan datang lebih awal ke sekolah".

Selanjutnya pendapat yang sama datang dari bapak Zondria (wawancara 22 Maret 2021), selaku wali kelas II di SD Negeri 01 Kinali, bapak Zondria mengatakan:"Guru merupakan panutan untu peserta diidknya. sebagai pendidik saya selalu memberikan contoh teladan yang baik kepada peserta didik. Dalam memberikan keteladanan, saya sebagai wali kelas harus mematuhi peraturan yang ada disekolah dan mencontohkan nya kepada peserta didik. Saya sudah memberikan contoh datang ke sekolah lebih awal, masuk ke kelas tepat waktu, serta memakai pakaian seragam dengan sopan dan rapi namun masih belum dilakukan sepenuhnya oleh seluruh pendidik karena masih terlihat 1-2 orang guru yang terlambat hadir di sekolah. Dan semua itu perlu pengawasan dari kepala sekolah.Sikap keteladanan yang kami berikan tidak hanya ditunjukkan dalam hal disiplin waktu namun juga dalam hal berpakaian". 
Risna Noviana dan Rini Rahman: Strategi Sekolah dalam Membentuk Sikap Disiplin Peserta Didik...

Menurut Supriyadi (2014) tugas utama dari seorang pendidik ialah sebagai pengajar dan serta harus memilki karakteristik atau kepribadian yang baik. Kepribadian yang mantap dari seorang pendidik akan menjadi teladan dan dicontoh oleh peserta didiknya. Kepribadian pendidik merupakan faktor yang penting bagi keberhasilan peserta didik dengan kata lain, pendidik memiliki pengaruh terhadap perubahan perilaku peserta didik. Guru itu merupakan sosok seseorang yang patut digugu yaitu mengikuti nesehat, ucapan atau perintahnya dan ditiru yaitu dicontoh sikap dan perilakunya.

Kedua, dengan pembiasaan. Berdasarkan hasil penelitian berupa wawancara kepada ibu Dila dari 24 Maret 2021 selaku wali kelas IV di SD Negeri 01 Kinali beliau berpendapat bahwa: "Sebagai wali kelas, saya mencontohkan kebiasaan-kebiasaan yang baik di dalam maupun di luar kelas. Ini merupakan langkah untuk menanamkan disiplin.Pembiasaan yang saya lakukan sebagai wali kelas dalam membentuk disiplin peserta didik melalui pelaksanaan tata tertib atau peraturan sekolah yaitu membiasakan diri untuk selalu taat dan patuh terhadap tata tertib yang berlaku.Untuk peserta didik yaitu dengan membiasakan peserta didik agar selalu melaksanakan kewajibannya seperti yang sudah tertulis dalam tata tertib siswa. Misalnya sebelum masuk kelas peserta didik kami biasakan berbaris dulu dengan rapi dan wajib berjabat tangan dan mencium tangan guru, memberi salam ketika masuk ke kelas, kemudian duduk dengan rapi setelah masuk kelas".

Menurut Suprayadi(2014) kebiasaan-kebiasaan yang baik sangat perlu diperhatikan sebagai unsur yang penting dalam proses pembentukan sikap disiplin peserta didik. Kebiasaan merupakan suatu perilaku yang dilakukan secara terus menerus. Dengan kebiasan bersikap displin yang diterapkan pendidik kepada peserta didik maka mereka lama-lama akan terbiasa melakukan hal hal yang dibiasakan oleh gurunya Jadi dalam membentuk sikap disiplin peserta didik pendidik harus senantiasa membiasakan peserta didik dengan menjaga sikap disiplin. Contohnya dari membiasakan datang ke sekolah tepat waktu, berbaris dengan rapi sebelum masuk ke kelas, ke sekolah berpakaian rapi, berdoa sebelum pelajaran dimulai, menjaga kebersihan lingkungan sekolah, dan kebiasaan lainya yang berhubungan dengan sikap disiplin peserta didik.

Ketiga, dengan mensosialisasikan peraturan, ini sesuai dengan pendapatBapak Arismel selaku wali kelas V (wawancara 25 Maret) mengatakan bahwa: "Cara yang dilakukan oleh guru-guru dalam mensosialisasikan peraturan atau sikap disiplin di sekolah yaitu menyampaikan pentingnya disiplin ketika di kelas maupun ketika upacara. Cara mensosialisasikan pembinaan sikap displin peserta didik adalah melalui papan peraturan sekolah, pada saat upacara bendera, dan ketika pada saat proses pembelajaran di kelas. Sebagai wali kelas saya biasanya menyuruh peserta didik membuat hiasan dinding yang bertuliskan peraturan sekolah, misal buanglah sampah pada tempatnya, dan tulisan dinding tersebut ditempel di dinding kelas, cara ini dilakukan agar peserta didik selalu ingat dengan peraturan sekolah".Selanjutnya 
ibu Titin selaku wali kelas I (wawancara 27 April 2021) mengatakan bahwa: "Ketika kami selaku pendidik mendapat giliran menjadi pembina upacara pada hari Senin kami selalu memberikan arahan pada peserta didik untuk selalu memperhatikan peraturan atau tata tertib sekolah. Komunikasi juga dilakukan oleh pendidik dengan cara mengajak peserta didik berdiskusi yang berhubungan dengan kedisiplinan terutama kedisiplinan belajar, dan juga peserta didik harus mampu bersikap disiplin baik di lingkungan sekolah, lingkungan keluarga dan juga masyarakat”.

Keempat, memberikan hukuman. Berdasarkan hasil wawancara dengan Ibu Emma selaku wali kelas VI SD Negeri 01 Kinali (wawancara 24 Maret), beliau menyampaikan bahwa: "Sebagai pendidik kami telah memberikan hukuman pada peserta didik yang melanggar peraturan. Hukuman yang diberikan agar memberikan efek jera kepada peserta didik untuk tidak mengulangi kesalahan nya kembali. Kami menerapkan hukuman kepada peserta didik yang melanggar peraturan sekolah.Hukuman yang kami berikan kepada peserta didik tidak berupa hukuman fisik atau hukuman berat, namun peserta didik lebih sering diberi teguran atau arahan. Dan jka terjadi pelanggaran biasanya mereka dihukum dengan cara disuruh menghafal dan membaca surah-surah pendek, membaca pancasila, dan hukuman yang paling sering diberikan ialah dengan teguran saja lalu diberikan nasehat".

Menurut Novitasari (2019) hukuman merupakan salah satu strategi yang digunakan oleh seorang pendidik dalam membentuk kedisiplinan peserta didik, hukuman yang diberikan berupa sanksi yang bersifat mendidik. Seorang pendidik dilarang memberikan hukuman yang menimbulkan kekerasan kepada peserta didik. Dalam membentuk sikap disiplin peserta didik di sekolah. Memberikan hukumandapat diterapkan sebagai motivasi atau dorongan bagi peserta didik agar dapat menjaga kedisipinannya.hukuman juga sangat perlu sebagai koreksi diri untuk berbuat yang positif dan pelajaran terhadap perbuatan negatif yang dilakukan oleh peserta didik.

Kelima, memberi penghargaan. Sesuai dengan pendapat bapak Budiarno selaku guru PAI mengatakan bahwa: "Kami sebagai pendidik memberikan penghargaan untuk mendorong peserta didik mengaktualisasikan dirinya. Penghargaan yang diberikan kepada peserta didik bertujuan agar peserta didik senang bersikap disiplin. Di SD Negeri 01 Kinali pendidik biasanya memberikan hadiah berupa buku tulis apabila peserta didik menerapkan kedisiplinan yang bagus di sekolah. Contoh penghargaan yang diberikan pendidik kepada peserta didik ketika dalam proses pembelajaran yaitu bagi peserta didik yang mengumpulkan tugas tepat waktu maka akan diberikan nilai tambahan sebagai bentuk apresiasi untuk mereka yang sudah disiplin dalam proses pembelajaran".

\section{Kendala yang dialami dalam Pembentukan sikap Disiplin Peserta Didik di SD Negeri 01 Kinali}

Dalam rangka membentuk disiplin siswa melalui pelaksanaan tata tertib di SD Negeri 01 Kinali ditemui beberapa kendala-kendala di antaranya sebagai berikut: 
Risna Noviana dan Rini Rahman: Strategi Sekolah dalam Membentuk Sikap Disiplin Peserta Didik...

Pertama, minimnya pengetahuan peserta didik tentang peraturan atau tata tertib sekolah. Sesuai dengan wawancara dengan kepala sekolahbapak Muksin (wawancara 12 April 2021), beliau mengatakan: "Pada saat upacara hari Senin, masih ada siswa yang tidak segera ke lapangan. Hal ini menunjukkan bahwa dalam diri siswa masih belum tertanam kesadaran diri padahal unsur ini merupakan unsur yang paling utama dalam membentuk disiplin terutama disiplin diri". Selanjutnya pendapat yang sama oleh bapak Zondria selaku wali kelas II (wawancara 14 April) mengatakan: "Kendala yang saya temukan ketika mengajarkan kedisiplinan kepada peserta didik ialah kurangnya pengetahuan peserta didik tentang tata tertib sekolah. banyak dari peserta didik saya tidak tahu dengan tata tertib sekolah. Hal itu terlihat dari beberapa peserta didik yang melanggar peraturan sekolah. Misalnya tidak memakai atribut lengkap ketika upacara bendera di lapangan sekolah, membuang sampah sembarangan, mencoret-coret bangku ketika sedang belajar dan berbagai macam pelanggaran lainya".

Menurut Anshori (2020) peran seorang pendidik sangat berpengaruh dan memegang peranan penting dalam memberikan pengetahuan kepada peserta didik tentang kedisiplinan.akan tetapi jika peran pendidik tersebut tidak berjalan sebagaimana mestinya maka bisa berdampak pada perilaku peserta didik. Apabila seorang siswa telah memiliki pengetahuan terhadap tata tertib maka mereka akan mengaplikasikannya dalam kehidupan sehari-hari ketika di sekolah dan mereka tidak akan melanggar karena sudah tahu perilaku mana yang tidak boleh dilakukan.

Kedua, rendahnya kesadaran peserta didik akan pentingnya kedisiplinan. Bapak Budiarno sebagai guru PAI di SD Negeri 01 Kinali (wawancara 16 April 2021) juga mengatakan bahwa: "Sebagai guru agama di SD Negeri 01 Kinali saya selalu mengajarkan karakter yang baik dan juga menanamkan kedisiplinan kepada peserta didik. Namun di sini tidak semua peserta didik yang menjaga kedisiplinan nya di sekolah. Salah satu contohnya ketika saya memberikan tugas untuk dikerjakan di rumah dan tidak semua peserta didik yang mengumpulkan tugas tersebut dengan tepat waktu".

Menurut (Aditya, 2018) disiplin akan lebih mudah ditegakkan apabila timbulnya kesadaran dalam diri peserta didik. Jika peserta didik memiliki kesadaran atau pikirannya telah terbuka untuk melaksanakan disiplin maka dengan mudah peseta didik tersebut akan melakukannya tanpa paksaan dari orang lain.

Ketiga, pengaruh pergaulan. Hasil wawancara penulis dengan Ibu Ema sebagai wali kelas VI pada tanggal 21 April 2021, beliau menyampaikan bahwa: "peserta didik bisa terpengaruh oleh teman ya di sekolah. Contoh peserta didik ikutikutan telat masuk ke kelas seperti hal nya waktu istirahtat kemudian bel masuk berbunyi, saya melihat si anak terkadang ingin masuk kelas namun karena dengan teman nya anak ini dipengaruhi untuk masuk kelas tidak tepat waktu.itu salah satu contohnya, jadi menurut saya lingkungan pergaulan yang tidak baik juga akan mempengaruhi disiplin peserta didik". Selanjutnya Selanjutnya ibu Dila selaku wali 
kelas III (wawancara 14 April 2021) juga mengatakan bahwa: "terkadang sikap peserta didik di sekolah juga dipengaruhi oleh pergaulan sesama temannya. Contohnya ada peserta didik yang sudah menerapkan disiplin yang baik di sekolah, namun karena sudah sering bergaul dengan peserta didik yang kurang menjaga sikap disiplin maka peserta didik tadi juga terpengaruh".

Menurut Gunawan (2011) Lingkungan di luar sekolah memang seringkali menjadi faktor penghambat dalam pembentukan disiplin di sekolah. Siswa yang tinggal di lingkungan yang tidak diterapkan aturan secara tegas dalam masyarakatnya akan membawa dampak negatif atau kebiasaan yang tidak baik ketika di sekolah. Begitu juga dengan pengaruh lingkungan pergaulan, jika teman dari peserta didik tersebut memiliki kebiasaan tidak patuh pada aturan/tidak mau diatur maka tidak menutup kemungkinan peserta didik itu bisa terpengaruh kebiasaan tidak baik.Oleh karena itu, peserta didik harus berhati-hati dalam bergaul dan memilih teman pergaulan.

\section{Solusi Untuk Mengatasi Kendala Kepala Sekolah dan Pendidik Dalam Membentuk Sikap Disiplin Peserta Didik di SD Negeri 01 Kinali.}

Berdasarkan kenyataan di lapangan menunjukkan bahwa pendidik masih menemukan kendala dalam membentuk sikap disiplin peserta didik,, sehingga harus dicarikan solusi untuk mengatasi kendala yang dialami. Solusi untuk mengatasi berbagai kendala tersebut di antaranya sebagai berikut:

Pertama, kerja sama elemen-elemen sekolah. Hasil wawancara bersama Bapak Muksin sebagai kepala sekolah di SD Negeri 01 Kinali (wawncara 23 April 2021) ialah: "upaya yang dilakukan dalam mengatasai kendala-kendala dalam membentuk sikap disiplin peserta didik ialah harus ada kerja sama elemen-elemen yang ada di sekolah. Pihak sekolah saling membantu dan punya peran yang sama, karena peserta didik yang belajar disini menjadi tanggung jawab pihak sekolah. Dalam rangka mengatasi masalah tersebut, tentunya sebagai kepala sekolah saya selalu selalu melakukan kontrol harian, mingguan dan bulanan kepada pendidik.Ini bertujuan untuk melihat sejauh mana perkembangan kedisiplinan peserta didik".

Menurut Yusuf, (2011) dalam pembentukan sikap disiplin peserta didik kerja sama antara elemen-elemen di sekolah sangat diperlukan baik itu pendidiknya maupun dari warga sekolah lainya terutama kepala sekolah. dibutuhkan kekompakan antara kepala sekolah, pendidik dan juga warga sekolah lainya dalam membentuk sikap disiplin peserta didik, jika elemen-elemen sekolah sudah melaksanakan tugas dengan sebaik-baiknya maka akan tercapai tujuan bersama yaitu membentuk sikap displin pada peserta didik dan dapat melaksanakan tata tertib sekolah yang telah ditetapkan.

Kedua, kerja pendidik dan orang tua. Hasil wawancara Ibu Titin sebagai wali kelas I (wawancara 27 April 2021), ia mengatakan bahwa: "untuk mendukung terbentuknya sikap disiplin peserta didik ialah diperlukan perhatian dari seorang 
pendidik dan juga kerjasama oran tua dan sekolah. Kerjasama yang kami lakukan dengan cara mengundang orang tua peserta didik dalam rapat-rapat yang berkaitan dengan kesiswaan dan juga secara langsung memanggil orang tua siswa yang bermasalah/melakukan pelanggaran tata tertib siswa untuk membicarakan dan memecahkan masalah-masalah. Dan orang tua tau bagaimana dengan perkembangan anak mereka di sekolah".

Menurut Wijaya, (2012) kerjasama pendidik dan orang tua perlu dijalin. Semua itu terjalin melalui komunikasi yang baik dan aktif, saling membantu dan mengetahui bagaimana upaya-upaya dalam membentuk kepribadian anak.Orang tua merupakan pendidik dan juga pelindung yang utama bagi anaknya, membiasakan disiplin dari orang tua ketika di rumah dan harus lebih intens dalam memperhatikan tumbuh kembang anak.

\section{Simpulan}

Berdasarkan hasil penelitian yang telah penulis teliti di SD Negeri 01 Kinali maka dapat ditarik beberapa kesimpulan sebagai berikut:

1. Strategi kepala sekolah dan pendidik dalam membentuk sikap disiplin ialah dengan strategi keteladanan, strategi pembiasaan yang dilakukan oleh guru, mensosialisasikan peraturan, pendidik memberikan hukuman bagi peserta didik yang melangagr peraturan, kemudian memberikan reward atau hadiah bagi mereka yang melaksanakan peraturan atau memiliki disiplin yang baik di sekolah.

2. Kendala yang ditemukan pendidik dalam membentuk sikap disiplin peserta didik ialah minimnya pengetahuan peserta didik akan peraturan sekolah, kurangnya kesadaran peserta didik akan pentingnya peraturan, dan kendala dari lingkungan pergaulan baik itu disekolah maupun di luar sekolah.

3. Solusi yang dilalui pendidik untuk menghadapi kendala dalam membentuk sikap disiplin peserta didik ialah dengan melakukan kerja sama yang baik anatara eleme-elemen sekolah (pihak sekolah), kemudian juga melakukan kerja sama yang baik antara pendidik dan orang tua.

\section{Referensi}

Aditya, W.K. 2018." Budaya Tertib Sisa Di Sekolah". Jawa Barat: CV Jejak

Anshori, Yoyo Zakaria. "Penguatan karakter disiplin siswa melalui peranan guru di sekolah dasar."Jurnal Elementaria Edukasia 3.1 (2020).

Asfiati.2020."Versi Program Merdeka Belajar Dalam Tiga Era”. Jakarta: Kencana

Darmadi.2017. "Pengembangan Model Metode Pembelajaran Dalam Dinamika Belajar

Siswa". Yogyakarta: Deepublish CV Budi Utama

Gunawan, Imam. 2019."Manajemen Kelas”. Depok: PT Raja Grafindo Persada 
Hidayatullah, M. Furqan. 2010. Pendidikan karakter. Membangun peradaban bangsa. Surakarta: Yuna Pustaka

Kusnandar, 2011. Guru Profesional. Jakarta: Raja Gravindo persada.

Lexy J Moleong. 2016. Metodologi Penelitian Kualitatif. Bandung: Remaja Rosdakarya

Mulyasa. E. 2013. Uji Kompetensi dan Penilaian Kinerja Guru. Bandung: Remaja Rosdakarya

Novitasari, Annisa. "Pemberian reward and punishment dalam membentuk karakter disiplin anak pada sekolah Madrasah Ibtidaiyah. "Halaqa: Islamic Education Journal 3.1 (2019): 27-33.

Sugiyono. 2007. Metode Penelitian Kuantitatif Kualitatif dan R\&D. Bandung: Alfabeta. Suprayadi. 2014. Strategi Belajar dan Mengajar. Yogyakarta: Jaya Ilmu Triatna

Cepi. 2016. Perilaku Organisasi dalam Pendidikan.Bandung: PT Remaja Rosdakarya Offset

Susanto, Ahmad. 2018. "Bimbingan dan Konseling di Sekolah". Jakarta: Prenada Media Syafril. 2017. "Dasar Dasar Ilmu Pendidikan". Depok: Kencana

Wijaya, Intan Apri, Okto Wijayanti, and Arifin Muslim. "Analisis Pemberian Reward dan Punishment pada Sikap disiplin SD N 01 Sokarja Tengah." Jurnal Education FKIP UNMA 5.2 (2019): 84-91.

Yusdiani, Nurmilah. 2018. Penanaman budaya disiplin peserta didik kelas vi MISS GUPPI Laikang Kecamatan Kajang Kabupaten Bulu Kumba. Skripsi. UIN Alauddin, Makassar.

Yusuf, Syamsu. 2011. Perkembangan Peserta Didik. Jakarta: PT. Raja Grafindo Persada 